\title{
Effect of Pasteurization Temperature on Sensory Stability of an Acidified Sugarcane Juice Beverage
}

Mariana T Kunitake, Cynthia Ditchfield, Carine O Silva and Rodrigo R Petrus*

University of São Paulo / School of Animal Science and Food Engineering / Department of Food Engineering - Av. Duque de Caxias Norte, 225 - CEP 13635-900 Pirassununga/SP, Brazil

\begin{abstract}
To evaluate the impact of pasteurization temperature on sensory stability of sugarcane juice with passion fruit pulp, nine batches of sugarcane juice with $4 \mathrm{~g} / 100 \mathrm{~g}$ passion fruit pulp were processed at $(85,90 \text { and } 95)^{\circ} \mathrm{C}$ for $30 \mathrm{~s}$, in triplicate). The pasteurized beverage was aseptically packaged in Polyethylene Terephthalate (PET) bottles and stored at $7^{\circ} \mathrm{C}$ in the dark. The beverage was characterized by physicochemical tests. Enzymatic activities of Polyphenol Oxidase (PPO) and Peroxidase (POD) were determined before and after processing. Coliforms and Salmonella counts were performed to ensure safety of the beverage safety. Psychrotrophic bacteria and yeasts and molds counts were carried out to assess the microbiological stability. Color parameters were measured in the processed juice throughout the storage period. A team of fifty panelists evaluated the appearance, aroma, flavor, and overall impression of the beverage using seven-point hedonic scale tests. Sensory stability was estimated by considering score averages above four and percentages of acceptance above $60 \%$. The $\mathrm{pH}$, soluble solids and titratable acidity of end product ranged from (3.96 to 4.19$)$, (19.7 to 20.1$)^{\circ} \mathrm{Brix}$, and (0.163 to 0.175$) \mathrm{g} / 100 \mathrm{~g}$ citric acid, respectively. The three processing binomials were effective for PPO inactivation; however, complete POD inactivation was reached at $95^{\circ} \mathrm{C} / 30$ s only. Coliforms and Salmonella counts were in compliance with Brazilian Regulations. The estimated sensory shelf-lives for sugarcane juice with passion fruit pulp processed at $(85,90 \text { and } 95)^{\circ} \mathrm{C} / 30 \mathrm{~s}$ were $(30,40$ and 50$)$ days, respectively. Thus, the increase of temperature pasteurization had a positive effect on product's stability.
\end{abstract}

Keywords: Shelf-life; Sugarcane juice; Pasteurization; Enzymatic activity; Aseptic filling

\section{Practical Application}

Sugarcane juice deteriorates rapidly even when refrigerated. Poor sanitary conditions during extraction of juices contribute to a fast deterioration of the product quality resulting in changes in appearance and flavor. This work suggests processing technologies to extend the product's shelf- life and shows that pasteurization temperature affects sensory stability to a large extent.

\section{Introduction}

Sugarcane juice has low acidity, high water activity and high sugar content and therefore deteriorates rapidly even when refrigerated [1]. Poor sanitary conditions during extraction also contribute to a fast deterioration of product's quality resulting in changes in appearance and flavor. In order to extend shelf-life of the product it is necessary to employ technologies to control the factors responsible for deterioration of the juice. The chemical, physical, sensory and nutritional attributes of sugarcane juice are affected by several factors that can be physical (light, heat), chemical (O2), biochemical (enzymes) and/or biological (microorganisms, insects).

Reduction of $\mathrm{pH}$ below 4.6 is an important action to inhibit growth of most pathogenic microorganisms. Addition of an acid fruit pulp acts as a barrier, preservating the beverage [2], though favorable growth of filamentous molds, yeasts and aciduric bacteria, which can be present in natural sugarcane microflora. Adoption of proper handling practices by sugarcane juice processors is essential to avoid contamination with pathogenic microorganisms $[3,4]$.

Darkening of sugarcane juice occurs by formation of brown pigments by enzymatic (Maillard reaction, thermal and alkaline degradation and sugar condensation) and non-enzymatic reactions (Maillard reaction, thermal and alkaline degradation and sugar condensation). During juice extraction exposure to oxygen initiates enzymatic browning caused by the activity of Peroxidase (POD) and
Polyphenol Oxidase (PPO) [5]. Both enzymes can be denatured by heat, reducing their activity and thus improving beverage stability, though POD has been found to be more resistant to thermal treatment than PPO in sugarcane juice [6].

Studies by Prati, Oliveira and Rezzadori $[7,8]$ and others have been accomplished in sugarcane juice pasteurization with and without addition of fruit juices, but the impact of pasteurization temperature on the sensory stability of sugarcane juice with passion fruit pulp, aseptically packed in plastic bottles has not yet been addressed. Thus, this study was undertaken to evaluate the effect of three pasteurization temperatures on the sensory stability of sugarcane juice acidified with passion fruit pulp and stored at $7^{\circ} \mathrm{C}$ as determined by the sensory scores obtained for appearance, aroma, flavor and overall impression.

\section{Materials and Methods}

\section{Raw materials}

Sugarcane (Sacharum officinarum) cultivar SP3250 was supplied by Tecnocana Sugarcane Technology Inc (Santa Cruz das Palmeiras, SP, Brazil). The juice was extracted and processed in a pilot plant at Department of Food Engineering, University of São Paulo, located approximately $30 \mathrm{~km}$ from the cultivation site.

*Corresonding author: Rodrigo Rodrigues Petrus, University of São Paulo School of Animal Science and Food Engineering/Department of Food Engineering - Av. Duque de Caxias Norte, 225 - CEP 13635-900 - Pirassununga/SP, Brazil, E-mail: rpetrus@usp.br

Received May 20, 2014; Accepted November 04, 2014; Published November 11,2014

Citation: Kunitake MT, Ditchfield C, Silva CO, Petrus RR (2014) Effect of Pasteurization Temperature on Sensory Stability of an Acidified Sugarcane Juice Beverage. J Food Process Technol 5: 399. doi:10.4172/2157-7110.1000399

Copyright: (c) 2014 Kunitake MT, et al. This is an open-access article distributed under the terms of the Creative Commons Attribution License, which permits unrestricted use, distribution, and reproduction in any medium, provided the original author and source are credited. 
Pasteurized and frozen yellow passion fruit pulp (Passiflora edulis) was acquired from the local market, processed by DeMarchi (Jundiaí, SP, Brazil).

\section{Processing}

Sugarcane was cut, scraped and then immersed in a sodium hypochlorite $(\mathrm{NaClO})$ solution containing $30 \mathrm{mg} / \mathrm{L}$ Free Residual Chlorine (FRC) for $20 \mathrm{~min}$ at a temperature of about $25^{\circ} \mathrm{C}$. Subsequently sugarcane juice was extracted in a stainless steel electric cylinder mill and $4 \mathrm{~g} / 100 \mathrm{~g}$ passion fruit pulp was added to the extracted juice, immediately after extraction to inhibit PPO activity and reduce juice $\mathrm{pH}$, thus obtaining acidified sugarcane juice.

Acidified juice was thermally processed in a plate heat exchanger (Sumá Indústria e Comércio Ltda, Campinas, SP, Brazil) composed of regeneration, heating, holding and cooling sections, with a nominal capacity of $300 \mathrm{~L} / \mathrm{h}$. The pasteurization binomials were $(85,90$ and $95)^{\circ} \mathrm{C}$ for $30 \mathrm{~s}$ and three alternated replicates were conducted for each condition. The juice was filtered, preheated to a temperature of about $50^{\circ} \mathrm{C}$, homogenized at $150 \mathrm{Bar}$ in a single stage homogenizer (Artepeças P\&B São Paulo, SP, Brazil), heated to the pasteurization temperature, cooled to approximately $8^{\circ} \mathrm{C}$ and pumped to an insulated buffer tank. A stainless steel, ISO Class 5 unidirectional air-flow cabin (Veco, Campinas, SP, Brazil) was used for aseptic filling of the juice into transparent $320 \mathrm{~mL}$ PET bottles. The packaging was previously decontaminated by dipping in a $0.05 \%(\mathrm{v} / \mathrm{v})$ peracetic acid (PAA) solution at $50^{\circ} \mathrm{C}$ for $30 \mathrm{~min}$. Figure 1 shows the processing flowchart.

\section{Physicochemical tests}

Physicochemical tests were performed as determined by the AOAC International [9]: the $\mathrm{pH}$ was determined using a digital meter Analyzer Model $300 \mathrm{M}$, the soluble solid contents (expressed as ${ }^{\circ} \mathrm{Brix}$ ) was determined using a Reichert AR 200 portable digital refractometer and the titratable acidity (expressed as \% citric acid): determined by titration with $0.1 \mathrm{M} \mathrm{NaOH}$ using phenolphthalein indicator.

\section{Determination of enzyme activity}

PPO and POD activities were determined according to the methods described by Campos and Silveira [10]. For the PPO activity, the phosphate buffer ( $\mathrm{pH}$ 6.0) and catechol were added to an aliquot of the sample and incubated at $30^{\circ} \mathrm{C}$ for $30 \mathrm{~min}$. The reaction was then terminated with perchloric acid, the absorbance was read in a spectrophotometer at $395 \mathrm{~nm}$. For the POD activity, phosphate buffer ( $\mathrm{pH}$ 5.0), hydrogen peroxide, an alcohol solution of guaiacol that was incubated at $30^{\circ} \mathrm{C}$ for $15 \mathrm{~min}$. The reaction was then terminated with sodium metabisulfite. Absorbance was read in a spectrophotometer at $470 \mathrm{~nm}$. A blank absorbance of sugarcane juice added to the phosphate buffer solution (substitute for the reagents) was determined.

Enzyme activity was expressed in $\mathrm{U} / \mathrm{mL}$ with one unit equivalent to a variation of 0.001 absorbance per minute per $\mathrm{mL}$ of sample. The Eq. 1 was applied to calculate the enzyme activity:

$$
\operatorname{Activity}(U / m l)=\frac{\left(A b_{\text {sample }}-A b_{\text {blank }}\right)}{0.001 \times t}
$$

where $\mathrm{Ab}$ sample is the sample absorbance; Ab blank is the blank absorbance; and $t$ the incubation time of sample with reagents (min).

\section{Microbiological tests}

Coliforms and Salmonella tests were carried out in compliance with Brazilian Regulations, Resolution number 12 from 2 January 2001, which requires that pasteurized and chilled pure sugarcane juice must present less than 10 coliforms at $45^{\circ} \mathrm{C} / \mathrm{mL}$ and absence of Salmonella spp./25 mL [11]. Psychrotrophic microorganism counts were carried to assess the product's microbiological stability while stored under refrigeration.

Coliform tests were performed according to the Most Probable Number (MPN) method. For Salmonella analysis, the 1-2 Test ${ }^{\circledast}$ from BIO- CONTROL was used. This test is a rapid analysis kit for the detection of mobile species of Salmonella in food, and it has been endorsed by the Association of Official Agricultural Chemists (AOAC) official method 989.13. The test is based on Salmonella immobilization in motility media using polyvalent $\mathrm{H}$ (flagellar) antibodies. The immobilization of mobile species of Salmonella results in the formation of a visible and well-defined band.

\section{Measurement of color}

Color parameters were measured in the processed juice throughout the storage period. A colorimeter (Ultra-Scan model SN7877, Hunterlab, Hunter Associates Laboratory Inc., Reston, VA, U.S.A.) and the CIELab coordinates were measured, using D65 illuminant and standard observer $\left(10^{\circ}\right)$. Three measurements were taken for each sample. Results for samples processed at different temperatures were compared as well as the variations observed along the storage period.

\section{Sensory tests}

The processed juice was submitted to sensory evaluation tests, using a seven-point hedonic scale, as described by Stone and Sidel [12]

The attributes appearance, aroma, flavor and overall impression

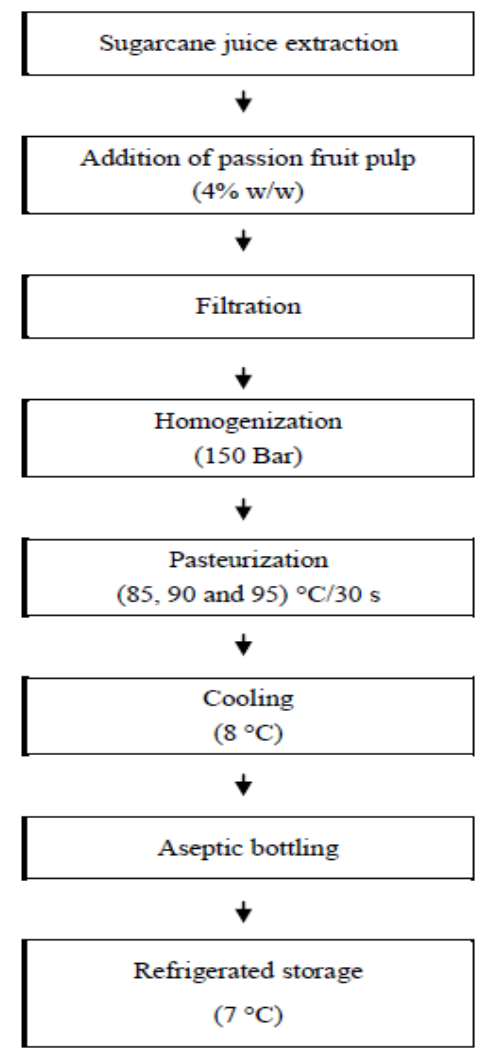

Figure 1: Flowchart of the experimental production of sugarcane juice acidified with passion fruit pulp 
were evaluated by 50 panelists, consumers of sugarcane juice. The juice was served at a temperature of about $12^{\circ} \mathrm{C}$. To estimate the sensory stability of the juice averages of above four points and at least $60 \%$ of acceptance were adopted as limit values. Sensory tests were performed in approximately 10 day intervals during the 60 days of storage at $7^{\circ} \mathrm{C}$. Processed sugarcane juice samples, used as control, were kept at $-18^{\circ} \mathrm{C}$ throughout the sensory stability study. Sensory tests were conducted every 10 days.

\section{Statistical analysis}

The statistical software program SAS 9.1 was used to perform Analysis of Variance (ANOVA) with a 95\% confidence level and comparison of means by the Tukey test.

\section{Results and Discussion}

As previously mentioned, nine batches of sugarcane juice with passion fruit pulp were processed, as follows: R1 (batches pasteurized at $85^{\circ} \mathrm{C} / 30 \mathrm{~s}$ ), $\mathrm{R} 2$ (batches pasteurized at $90^{\circ} \mathrm{C} / 30 \mathrm{~s}$ ) and $\mathrm{R} 3$ (batches pasteurized at $95^{\circ} \mathrm{C} / 30 \mathrm{~s}$ ).

\section{Physicochemical characterization}

The means and standard deviations of the results obtained in the physicochemical tests are shown in Table 1, for the three batches of each replicate.

According to results shown in Table 1, there were no statistic differences among mean values obtained from both fresh sugarcane juice and acidified juice, regarding the extraction yield, $\mathrm{pH}$, soluble solids and titratable acidity. Some differences in the characteristics of the sugarcane juice may be attributed to variations in the plant composition due to different periods of planting, harvesting times, climatic conditions and maturation stages, in spite of the fact that the raw material batches belonged to the same cultivar and originated from the same production source.

The yield variation between the averages of replicates, which ranged from (52.1 to 54.9$) \%$, can be explained by the periods of drought and rain observed throughout the research. Mao and others [13] found an average yield of $70.8 \%$. The difference between this result and that of the present study may be related to the sugarcane variety used, its maturation stage and the juice extraction method. Higher levels are usually obtained on an industrial scale and are made possible by the enzymatic treatment of the bagasse.

Oliveira determined a $\mathrm{pH}$ of 5.28 , soluble solids content of 22.7 ${ }^{\circ}$ Brix and titratable acidity of $0.04 \%$ citric acid for natural sugarcane juice. These values are similar to those determined in this study.

A pH below 4.6 classifies the sugarcane juice with added passion fruit pulp as an acidified beverage, which favors microbiological stability, restricting bacterial growth and enzymatic stability and inhibiting enzyme action, especially the PPO system, which has an optimum performance $\mathrm{pH}$ close to 7.2 (Gomes and others 2001). Moreover, the citric acid in the passion fruit pulp complexes with the copper $\left(\mathrm{Cu}^{2}+\right)$ present in the PPO active site, therefore inhibiting enzymatic browning of the juice [14].

The addition of acidic fruit pulps, such as passion fruit, to sugarcane juice in small proportions also improves the sensory quality of the beverage. Acidic fruit pulps promote a change in the relationship between the soluble solid contents and the titratable acidity, thus softening the perception of sweetness and providing a refreshing taste $[15,16]$.

\section{Enzymatic activity}

PPO and POD activity in fresh sugarcane juice varied between ( 40.3 and 40.9) $\mathrm{U} / \mathrm{ml}$, and between (100.2 and 226.1) $\mathrm{U} / \mathrm{ml}$; respectively. After addition of passion fruit pulp PPO activity reduced to between (17.2 and 27.8) $\mathrm{U} / \mathrm{ml}$ while POD activity was between (107.9 and 163.4) $\mathrm{U} / \mathrm{ml}$. PPO was inactivated by all the pasteurization temperatures $(85$, 90 and $95^{\circ} \mathrm{C}$ ) since no residual activity was detected in processed samples. On the other hand, POD presented residual activities between (0.1 and 17.9) $\mathrm{U} / \mathrm{ml}$. These results demonstrate that the three time/ temperature binomials $(85,90 \text { and } 95)^{\circ} \mathrm{C}$ for $30 \mathrm{~s}$ effectively inactivated $\mathrm{PPO}$, but to inactivate POD it is necessary to process at the most severe binomial $\left(95^{\circ} \mathrm{C}\right.$ for $\left.30 \mathrm{~s}\right)$, as reported by Cunha and others [17] and Brito and others [18]. POD stability is decreased by lowering the $\mathrm{pH}$, which favors its inactivation. The variation in enzyme activity can be attributed to raw material composition variability, which is common in vegetable products.

Mao and others reported that PPO activity converts phenolic compounds into brown colored polymers, which causes darkening when sugarcane is crushed. Despite inactivation of PPO during pasteurization alterations in color were still observed, suggesting that other mechanisms, like chlorophyll degradation also occur.

The results demonstrate that the characteristics of the raw materials are significantly affected by the harvest period and therefore the industrial process must consider this.

Sugarcane juice browning is initiated by the enzymatic oxidation of phenolic compounds, which forms dark, insoluble pigments; therefore, the quantity and availability of phenolic compounds in the presence of oxygen is a major factor in the analysis of the beverage browning. Moreover, high enzymatic activity increases the browning speed, decreasing the acceptability of the beverage. Therefore, it is essential to inactivate the enzymes in the beverage.

\section{Microbiological tests}

Table 2 shows the results for the analysis of coliforms and Salmonella in the pasteurized beverage samples.

Table 2 shows that coliforms at $(35 \text { and } 45)^{\circ} \mathrm{C}$ mean counts were below $4 \mathrm{MPN} / \mathrm{ml}$ for replicates 1,2 and 3. Prati [19] examined sugarcane juice with passion fruit juice that had been clarified and cooled to (4$6)^{\circ} \mathrm{C}$, obtaining coliform values below $0.03 \mathrm{MPN} / \mathrm{ml}$ at $35^{\circ} \mathrm{C}$. Rezzadori obtained coliform values below $0.3 \mathrm{MPN} / \mathrm{ml}$ at $45^{\circ} \mathrm{C}$ and absence of Salmonella in sugarcane juice with addition of passion fruit pulp.

All batches processed in the present study complied with Brazilian Regulations, which states that the beverage must present a coliform count at $45^{\circ} \mathrm{C}$ below $10 \mathrm{MPN} / \mathrm{ml}$ and absence of Salmonella sp. in 25 $\mathrm{ml}$ of sample.

Pshychrotrophic bacteria counts throughout the 60 days storage period varied from ( 1 to 47 ) $\mathrm{CFU} / \mathrm{ml}$, while yeasts and molds counts ranged from (1 to 23 ) CFU/ml. These results indicate that the product presented microbiological stability when kept at $7^{\circ} \mathrm{C}$.

\section{Beverage color}

Table 3 presents the results for observed variation in CIELab color parameters when compared to the unprocessed beverage for each processing temperature.

Processed beverages presented higher $L$ values than the unprocessed ones, indicating that they had a lighter color. Processing at (90 or 


\begin{tabular}{|l|l|l|l|}
\hline FRESH SUGARCANE JUICE & $\mathbf{R}^{\mathbf{a}}$ & $\mathbf{R 2}^{\mathbf{b}}$ & $\mathbf{R 3}^{\mathbf{c}}$ \\
\hline Extraction yield1 $(\%)$ & $54.7 \mathrm{a} \pm 5.5$ & $54.9 \mathrm{a} \pm 5.5$ & $52.1 \mathrm{a} \pm 5.9$ \\
\hline pH & $5.16 \mathrm{a} \pm 0.16$ & $5.27 \mathrm{a} \pm 0.08$ & $5.27 \mathrm{a} \pm 0.31$ \\
\hline Soluble solids ( ${ }^{\circ}$ Brix) & $21.1 \mathrm{a} \pm 2.2$ & $18.3 \mathrm{a} \pm 4.0$ & $20.3 \mathrm{a} \pm 3.2$ \\
\hline $\begin{array}{l}\text { Titratable acidity }(\% \text { citric } \\
\text { acid) }\end{array}$ & $0.052 \mathrm{a} \pm 0.015$ & $0.050 \mathrm{a} \pm 0.009$ & $0.047 \mathrm{a} \pm 0.011$ \\
\hline ACIDIFIED JUICE & & & \\
\hline pH & $4.19 \mathrm{a} \pm 0.16$ & $4.07 \mathrm{a} \pm 0.21$ & $3.96 \mathrm{a} \pm 0.17$ \\
\hline Soluble solids ( ${ }^{\circ}$ Brix) & $20.1 \mathrm{a} \pm 2.6$ & $20.1 \mathrm{a} \pm 4.6$ & $19.7 \mathrm{a} \pm 2.5$ \\
\hline $\begin{array}{l}\text { Titratable acidity }(\% \text { citric } \\
\text { acid) }\end{array}$ & $0.175 \mathrm{a} \pm 0.033$ & $0.163 \mathrm{a} \pm 0.013$ & $0.167 \mathrm{a} \pm 0.046$ \\
\hline
\end{tabular}

${ }^{\text {aR } 1}$ - average of batches 1,4 and 7 (pasteurized at $85^{\circ} \mathrm{C} / 30 \mathrm{~s}$ ).

${ }^{\mathrm{b}} \mathrm{R} 2$ - average of batches 2,5 and 8 (pasteurized at $90^{\circ} \mathrm{C} / 30 \mathrm{~s}$ ).

${ }^{\mathrm{C}} \mathrm{R} 3$ - average of batches 3,6 and 9 (pasteurized at $95^{\circ} \mathrm{C} / 30 \mathrm{~s}$ ).

1 In relation to peeled sugarcane. Mean values followed by the same letter, in the same row, are not different ( $p>0.05)$.

Table 1: Average physicochemical characteristics of the acidified sugarcane juice beverage processed in each replicate

\begin{tabular}{|l|c|c|c|}
\hline Replicate & R1 $^{\mathbf{a}}$ & $\mathbf{R 2}^{\mathbf{b}}$ & $\mathbf{R 3}^{\mathbf{c}}$ \\
\hline Coliforms at $\mathbf{3 5}^{\circ} \mathbf{C}$ (MPN/ml) & $3.9 \pm 1.6$ & $3.8 \pm 1.4$ & $3.0 \pm 0.0$ \\
\hline Coliforms at $\mathbf{4 5}^{\circ} \mathbf{C}$ (MPN/ml) & $<3.0$ & $<3.0$ & $<3.0$ \\
\hline Salmonella sp. (in $\mathbf{2 5} \mathbf{~ m l )}$ & Absent & Absent & Absent \\
\hline
\end{tabular}

${ }^{\text {aR }} 1$ - average of batches 1,4 and 7 (pasteurized at $85^{\circ} \mathrm{C} / 30 \mathrm{~s}$ ).

${ }^{\mathrm{b}} \mathrm{R} 2$ - average of batches 2,5 and 8 (pasteurized at $90^{\circ} \mathrm{C} / 30 \mathrm{~s}$ ).

${ }^{\mathrm{C}} \mathrm{R} 3$ - average of batches 3,6 and 9 (pasteurized at $95^{\circ} \mathrm{C} / 30 \mathrm{~s}$ ).

Table 2: Microbial counts $(\mathrm{CFU} / \mathrm{ml})$ in sugarcane juice with passion fruit pulp, pasteurized and aseptically bottled

\begin{tabular}{|c|c|c|c|}
\hline Processing temperature $\left({ }^{\circ} \mathbf{C}\right)$ & $\boldsymbol{\Delta L}^{\mathbf{1}}$ & $\boldsymbol{\Delta} \mathbf{a}^{\mathbf{1}}$ & $\boldsymbol{\Delta} \mathbf{b}^{\mathbf{1}}$ \\
\hline $\mathbf{8 5}$ & $2 \mathrm{a} \pm 2$ & $-0.1 \mathrm{a} \pm 0.5$ & $0.6 \mathrm{a} \pm 1.8$ \\
\hline $\mathbf{9 0}$ & $6 \mathrm{~b} \pm 4$ & $-0.3 \mathrm{a} \pm 0.3$ & $1 \mathrm{a} \pm 1$ \\
\hline $\mathbf{9 5}$ & $6 \mathrm{~b} \pm 2$ & $-0.1 \mathrm{a} \pm 0.6$ & $0.0 \mathrm{a} \pm 0.5$ \\
\hline
\end{tabular}

${ }^{1}$ Averages of three batches, in the same column, followed by the same letter do not differ at $5 \%$ significance level.

Table 3: Comparison of the variation in CIELab color parameters in relation to 422 unprocessed beverage at each processing temperature

$95)^{\circ} \mathrm{C}$ results in a significant increase in the $\mathrm{L}$ value when compared to the beverages processed at $85^{\circ} \mathrm{C}$. This may be due to a greater enzyme inactivation at the higher processing temperatures. For a and $\mathrm{b}$ values significant differences were not found for different processing temperatures. A large variability is observed for the results probably because of the variations in raw material composition.

Figure 2 shows the variation in color parameters of the processed beverage during the storage period. It can be observed that all batches except 4 and 5 were darker after 4 weeks storage. Variations in $\Delta$ a were slight and a definite trend could not be observed. For replicates 2 and 3 an increase in processing temperature results in higher $\Delta \mathrm{b}$ values, indicating a slightly stronger yellow color. Comparison of $L$ values for batches 1, 2 and 3 show that the beverage was significantly darker after 4 weeks storage and further increase in the storage period maintained this difference. The $\mathrm{a}$ and $\mathrm{b}$ color parameters both tend to present a slight increase during storage but a definite trend could not be established. Enzyme activity after processing, particularly for peroxidase (higher thermal resistance) may be responsible for the color changes observed.

Beverage appearance scores seem to be related to the color parameter values. Lower sensory scores were observed for beverages with higher values (shift towards red color). For batch 6 for example after 4 weeks storage the average appearance scores were statistically similar to the freshly processed beverage. The color parameters indicate a significant decrease in the $\mathrm{L}$ value after 4 weeks storage but no significant difference for $\mathrm{a}$ and $\mathrm{b}$ values. After 8 weeks

storage the $\mathrm{L}$ value maintained the difference, the a value increased significantly and the $\mathrm{b}$ value presented no significant difference (with respect to the freshly processed beverage). However average appearance scores were significantly lower after 8 weeks storage. This same trend can be observed for all the processed batches. It must be noted that sensory evaluation of appearance involves other attributes like homogeneity of sample and also that color change is a combination of the $\mathrm{L}$, $\mathrm{a}$ and $\mathrm{b}$ values.

\section{Sensory evaluation}

Beverage stability is commonly affected by many intrinsic and extrinsic factors; therefore, sensory analysis is an essential and rapid consumer response tool to evaluate the effect of procedures and treatments performed on the product.

Table 4 presents results obtained for the hedonic scale tests of the three replicates carried out at the beginning, middle and end of the storage period. The values in bold indicate acceptance percentages $\leq$ $60 \%$.

The results shown in Table 4 demonstrate that the batches processed at $(85,90 \text {, and } 95)^{\circ} \mathrm{C}$ for $30 \mathrm{~s}$ initially obtained high sensory acceptance scores. The acceptability of the beverages processed in all three conditions initially varied from (82 to 99$) \%$ for all tested attributes. According to Teixeira and Dutcoski [20,21], approval scores above $70 \%$ indicate high acceptance of the product.

The average scores and acceptance percentages of the samples stored at $7{ }^{\circ} \mathrm{C}$ and of the control samples were similar up to 30 days of storage. After a 60 day storage period the acceptance scores reduced significantly, especially for the batches pasteurized at $85^{\circ} \mathrm{C}$, suggesting a higher quality degradation of the beverage processed at this temperature.

Prati studied the shelf-life of clarified and stabilized sugarcane juice with $5 \mathrm{~g} / 100 \mathrm{~g}$ of passion fruit pulp and concluded that average scores for color, taste and overall impression (using a 9 point unstructured hedonic scale) reduced significantly during 30 days of refrigerated (4$6)^{\circ} \mathrm{C}$ storage.

\section{Estimation of sensory stability}

Figure 3 presents the values obtained for estimating sensory stability of the processed sugarcane juice stored under refrigeration in the dark, according to acceptance percentage shown in Table 4.

Figure 3 demonstrates that sensory stability of the beverage was positively impacted by increasing pasteurization temperature, probably due to enzyme inactivation.

Oliveira determined that a pasteurized sugarcane juice beverage with $4 \mathrm{~g} / 100 \mathrm{~g}$ of lemon juice packaged in high density polyethylene bottles and kept under refrigerated storage maintained a satisfactory quality for 42 days. This result is similar to that obtained for the beverage pasteurized at $90^{\circ} \mathrm{C}$ in this study.

In this study the thermal treatment at $95^{\circ} \mathrm{C} / 30 \mathrm{~s}$ proved to be effective in maintaining an acceptable level of quality of the juice, under refrigeration, for a period compatible with the consumer market demand. 
Citation: Kunitake MT, Ditchfield C, Silva CO, Petrus RR (2014) Effect of Pasteurization Temperature on Sensory Stability of an Acidified Sugarcane Juice Beverage. J Food Process Technol 5: 399. doi:10.4172/2157-7110.1000399

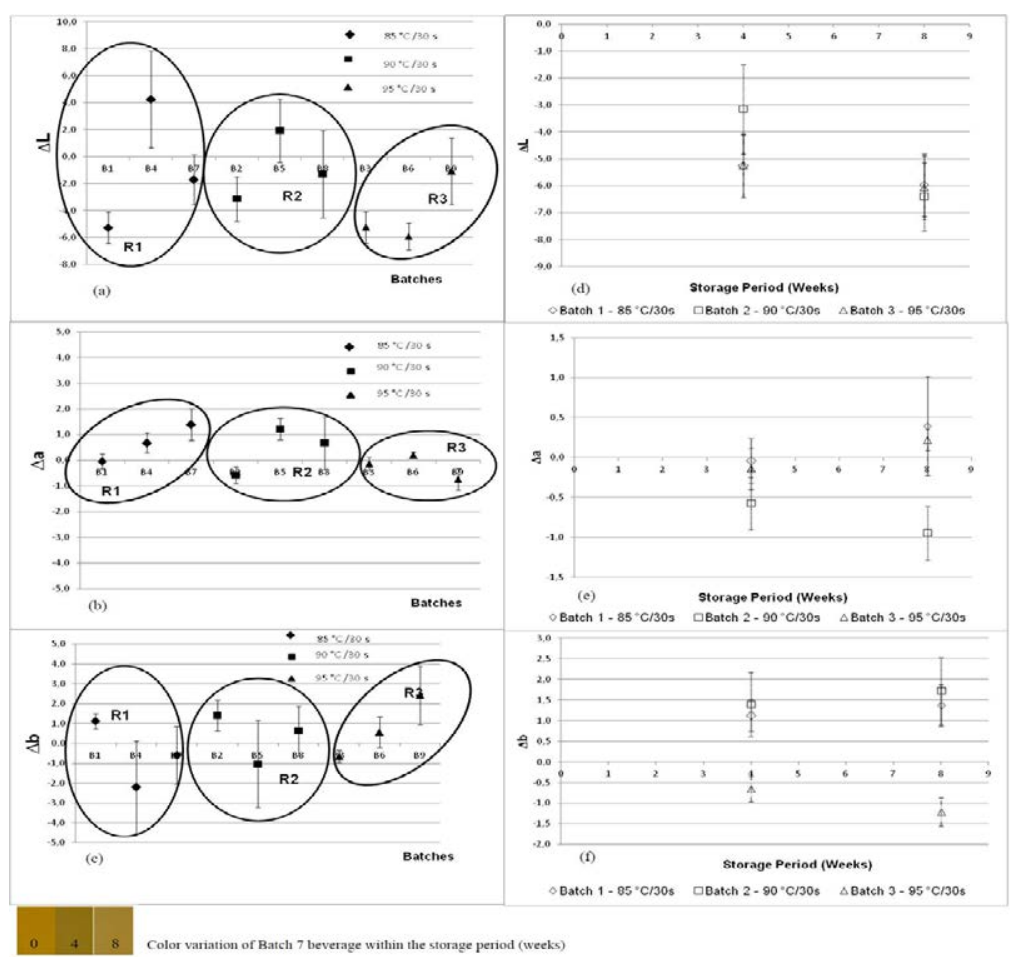

Figure 2: Difference in CIELab color parameters during storage in relation to freshly processed beverage (a) $\Delta L$ for batches 1 to 9 after 4 weeks storage (b) $\Delta$ a for batches 1 to 9 after 4 weeks storage (c) $\Delta b$ for batches 1 to 9 after 4 weeks storage (d) $\Delta L$ for batches 1,2 and 3 throughout the storage period (e) $\Delta a$ for batches 1,2 and 3 throughout the storage period (f) $\Delta b$ for batches 1,2 and 3 throughout the storage period (R1, R2 and R3 refer to the replicates of processing conditions)

\begin{tabular}{|c|c|c|c|c|c|c|c|c|c|}
\hline \multicolumn{10}{|c|}{ Evaluated attribute (average scores / \% acceptance1) } \\
\hline \multirow[b]{2}{*}{ Thermal treatment } & \multirow{2}{*}{$\begin{array}{l}\text { Storage at } 7 \\
{ }^{\circ} \mathrm{C} \text { (days) }\end{array}$} & Appearance & \multirow[b]{2}{*}{ Sample } & \multirow[b]{2}{*}{ Aroma } & \multirow[b]{2}{*}{ control } & \multirow[b]{2}{*}{ sample } & \multirow[b]{2}{*}{ Flavor } & \multirow[b]{2}{*}{ control } & \multirow{2}{*}{\begin{tabular}{|l} 
Final Values \\
sample control
\end{tabular}} \\
\hline & & $S \underset{\text { Control }}{S}$ & & & & & & & \\
\hline & 0 & $6.0 / 92$ & & $6.3 / 97$ & & & $5.8 / 95$ & & $5.9 / 99$ \\
\hline \multirow{3}{*}{$85^{\circ} \mathrm{C} / 30 \mathrm{~s}$} & 30 & $5.7 / 875.8 / 85$ & $5.7 / 92$ & & $5.8 / 91$ & $5.4 / 92$ & & $5.6 / 86$ & $5.5 / 945.6 / 89$ \\
\hline & 60 & $4.7 / 546.1 / 96$ & $4.6 / 54$ & & $6.1 / 92$ & $4.1 / 44$ & & $5.8 / 90$ & $4.4 / 485.9 / 96$ \\
\hline & 0 & $6.1 / 92$ & & $6.4 / 97$ & & & $5.8 / 90$ & & $5.9 / 93$ \\
\hline \multirow{3}{*}{$90^{\circ} \mathrm{C} / 30 \mathrm{~s}$} & 30 & $5.8 / 866 / 92$ & $5.8 / 81$ & & $5.8 / 88$ & $5.2 / 74$ & & $5.5 / 82$ & $5.4 / 805.7 / 88$ \\
\hline & 60 & $5.6 / 796 / 92$ & $5.3 / 73$ & & Jun-93 & $4.8 / 60$ & & $5.4 / 80$ & $5.2 / 735.7 / 86$ \\
\hline & 0 & Jun-91 & & Jun-91 & & & $5.5 / 82$ & & $5.8 / 88$ \\
\hline \multirow{2}{*}{$95^{\circ} \mathrm{C} / 30 \mathrm{~s}$} & 30 & $5.6 / 836.3 / 96$ & $5.6 / 82$ & & Jun-95 & May-67 & & $5.8 / 93$ & $5.2 / 726 / 94$ \\
\hline & 60 & $5.5 / 816 / 93$ & $5.4 / 81$ & & $5.9 / 86$ & May-60 & & $5.7 / 84$ & $5 / 705.7 / 92$ \\
\hline
\end{tabular}

${ }^{1}$ Percentage of panelists that assigned scores above 4

Control, juice stored at $-18^{\circ} \mathrm{C}$; Number of panelists, 50 ; Serving temperature, $(12-13)^{\circ} \mathrm{C} ; 7$ point hedonic scale, $(1=$ dislike extremely; $4=$ neither like/nor dislike; $7=$ like extremely)

Table 4: Average sensory acceptance scores for sugarcane juice with passion fruit pulp

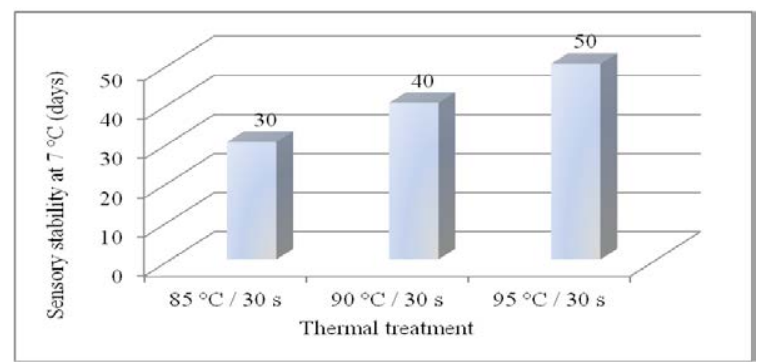

Figure 3: Estimation of sensory stability of pasteurized sugarcane juice with passion fruit pulp
The shelf-life of sugarcane juice is somewhat variable and depend on the physicochemical and microbiological characteristics of raw material, processing technology, packaging system, barrier properties of the packaging material and fundamentally, the temperature of distribution, storage and commercialization.

The browning and the onset of off flavors are the main factors that lead to rejection of sugarcane juice, due to chemical, enzymatic and microbiological mechanisms [22].

Apart of this, the choice of a raw material cultivar less susceptible to enzymatic browning, along with the use of proper processing technologies are highly recommended actions. 
Citation: Kunitake MT, Ditchfield C, Silva CO, Petrus RR (2014) Effect of Pasteurization Temperature on Sensory Stability of an Acidified Sugarcane Juice Beverage. J Food Process Technol 5: 399. doi:10.4172/2157-7110.1000399

\section{Conclusion}

All the batches of processed sugarcane juice presented a high sensory acceptance, particularly in the initial period of the stability tests. Throughout the storage period Psychrotrophic microorganism's counts were very low indicating that the beverage was microbiologically stable. Complete inactivation of peroxidase required a processing temperature of $95^{\circ} \mathrm{C}$ for 30 s. Pasteurization temperature affected sensory stability to a large extent, an increase in temperature resulted in higher stability and a gain in product shelf-life.

\section{Acknowledgments}

The authors gratefully acknowledge the Foundation for Research Support of Soaulo (FAPESP) for funding this research, and Tecnocana Tecnologia em Cana Ltda., for providing the raw material.

\section{References}

1. Yusof S, Shian LS, Osman A (2000) Changes in quality of sugar-cane juice upon delayed extraction and storage. Food Chem 68: 395-401.

2. Silva N, Junqueira VCA, Silveira NFA, Taniwaki MH, Santos RFS, et al. (2007) Manual of methods for the microbiological analysis of foods. São Paulo: Varela.

3. Vanzo SP, Azevedo RVP (2003) Detection of S. aureus in food handlers: profile of resistance to antibiotics and chemotherapy. Hig Aliment 17: 114-123.

4. Oliveira ACG (2007) Effects of thermal processing and gamma radiation on the physicochemical, microbiological and sensory stability of pure sugarcane juice with fruit juice stored under refrigeration. [Master thesis]. Piracicaba: Luiz de Queiroz College of Agriculture.

5. Qudsieh HY, Yusof S, Osman A, Rahman RA (2002) Effect of maturity on chlorophyll, tannin, color, and polyphenol oxidase (PPO) activity of sugarcane juice (Saccharum officinarum Var. Yellow Cane). J Agric Food Chem 50: 1615-1618.

6. Bucheli CS, Robinson SP (2004) Contribution of enzymatic browning to color in sugarcane juice. J Agric Food Chem 42: 257-261.

7. Prati P, Moretti RH, Cardello HMAB (2005) Elaboration of a beverage composed of a mixture of partially clarified-stabilized sugarcane juice and acidic fruit juices. Ciênc Tecnol Aliment 25: 147-152.

8. Rezzadori K (2010) Thermal pasteurization with membranes of sugarcane juice with added passion fruit juice. Florianópolis: Federal University of Santa Catarina.
9. AOAC (1997) Official methods of analysis. (16th Edition). Arlington, VA Association of Official Analytical Chemistis.

10. Campos AD, Silveira EML (2003) Methodology for the determination of peroxidase and polyphenol oxidase in plants. Comunicado técnico 87 Embrapa. Pelotas.

11. Brazil (2001) Ministry of Health. National Health Surveillance Agency Technical regulation on microbiological standards for foods. Diário Oficial da União Section.

12. Stone H, Sidel JL (1985) Sensory evaluation practices. Academic Press. London.

13. Mao LC, Xu YQ, Que F (2007) Maintaining the quality of sugarcane juice with blanching and ascorbic acid. Food Chem 104: 740-745.

14. Romano CM (2006) Physicochemical and cooking characteristics of beans (Phaseolus vulgaris L.). CV. Bright Guapo due to stationary drying and time of conventional storage. Pelotas: Federal University of Pelotas.

15. Thé PMP, Carvalho VD, Abreu CMP, Nunes RP, Pinto NAVD (2001) Effects of storage temperature and ripening stage on the chemical composition of pineapple cv. Smooth cayenne. Ciênc Agrotec 25: 356-363.

16. Matsura FCAU, Folegatti MIS, Cardoso RL, Ferreira DC (2004) Sensory acceptance of mixed nectar papaya, passion fruit and acerola. Sci Agric 61 604-608.

17. Cunha GMA, Alves JKP, Júnior WMA, Duarte WKC, Magalhães MMA (2005) Study of the thermal inactivation kinetics of peroxidase present in guava pulp. Proceeding of the 6th Brazilian Congress of Chemical Engineering in Scientific Initiation. Campinas, Brazil.

18. Brito CAK, Sato HH, Spironello A, Siqueira WJ (2005) Characteristics of the peroxidase activity of the pineapple Ananas comosus ((L.) Merrill) cultivar IAC slice honey and clone IAC-1. Ciênc Tecnol Aliment 25: 244-249.

19. Prati $P$ (2004) Development of a process for the stabilization of sugarcane juice with acidic fruit juices. Campinas: State University of Campinas.

20. Teixeira E, Meinert EM, Barbetta PA (1987) Sensory analysis of food. Florianópolis: UFSC

21. Dutcoski SD (1996) Sensory Analysis of Foods. Curitiba: Editora Universitária

22. Gomes MRA, Oliveira MGA, Carneiro GES, Barros EG, Moreira MA (2001) Physicochemical properties of bean polyphenyloxidase (Phaseolus vulgaris L.). Ciênc Tecnol Aliment 21: 69-72. 